\title{
Honorific Representation in Javanese Language Book for Junior High School
}

\author{
Tri Widiatmi ${ }^{1}$, St.Y. Slamet ${ }^{2}$, Sahid Teguh Widodo ${ }^{3}$, Kundharu Saddhono ${ }^{4}$ \\ $\left\{\right.$ triwidiatmi@gmail.com, ${ }^{2}$ slametsty@yahoo.co.id, \\ 3sahidteguhwidodo@yahoo.com, ${ }^{4}$ kundharu.uns@.gmail.com? \\ 1,2,3,4 Sebelas Maret University, Indonesia \\ ${ }^{1}$ Universitas Bangun Nusantara, Indonesia
}

\begin{abstract}
This research aimed to explore the representation of Javanese honorific lexicon in Javanese textbook. This research employed a descriptive qualitative approach by analyzing two Javanese-language books used in learning Javanese language in junior high school. This research was conducted using textual analysis method to map honorific vocabulary and literature study. The result of research showed that Javanese-language textbook is one of vehicles to achieve competency. Nevertheless, teaching material sometimes pays attention inadequately to honorific use to others. The honorific use in Javanese language can function to be identity and communication medium for the speaker. Honorific use in Javanese social culture can indicate the politeness of corresponding language user. The use of Javanese language reflecting politeness is conducted by using fine lexicon form. Fine lexicon is used to respect the speech partner. Fine lexicon can be used as honorific lexicon to others. Honorific lexicon in Javanese textbook is represented in teaching material in the form of lexicon form and lexicon form use. The option of lexicon form chosen was fine lexicon. The use of lexicon was adjusted with situation and social factor.
\end{abstract}

Keywords: Javanese, speech level, honorific

\section{Introduction}

Bahasa dapat digunakan sebagai penanda identitas individu atau kelompok [1], [2]. Honorific is intended to be teaching material in language textbook. Language functions to be a communication medium. Some studies having been conducted focused on the use of honorific [3]-[8] corresponding to culture through diction and vocabulary substitution designating the social relation with speech partner and third person [9]. Brown shows the importance of honorific use and speech level in Korean people. Korean people use honorific and speech levels widely in their language use. Figure of speech uses honorific through learning design, implementation, and evaluation used for teaching activity [10]. Honorific is used to shows the relationship between speaker (author) and others through special or ordinary noun, using suffix or pronoun. Japanese speaker uses honorific in daily social interaction by considering linguistic and sociolinguistic rules [11]. The result of research conducted in Japan shows that 
the use of honorific in verbal and non-verbal communication will support the successful daily communication and the professional life [12]. Law mandates the consistency with the Standard Content [13], as included in the attitude competency such as interacting politely and effectively in social and natural environment in interaction coverage and its existence.

The definition of honorific, according to Indonesian Language Big Dictionary, is related to the use of respecting expression in language to address a certain person. In literature review on honorific, it can be found that honorific is the expression of respect to speech partner by applying the principles of enhancing speech partner and humbling the self [14].

The problem arises when students cannot use appropriate language in communicating. Language textbook emphasizes more on the achievement of other competencies, so that the form of honorific sentence is mastered poorly. The use of language to communicate appropriately is desirable to be given to students. The use of honorific to address the speech partner whose status is higher is very important to the learning as an attempt of inculcating social-cultural values. The implication of research can benefit the development of language teaching material, particularly in the use of honorific forms.

\section{Research Method}

Javanese language has speech level (unggah-ungguh) that is still maintained and used by its speakers [15]. The use of speech level can represent politeness in speaking with the speech partner. It is dependent on vocabulary (lexicon) use and choice. Javanese lexicon, by its form, is divided into six: ngoko, madya, krama, krama inggil, krama andhap, and neutral. Meanwhile, by viewed from its meaning or pragmatically, Javanese language lexicon is divided into three: fine, common (ordinary), and crude. In relation to feeling value, fine lexicon is the one reflecting politeness [14]. Fine lexicon often used to respect the speech partner is honorific lexicon. In Karti Basa, basa krama is the language replete with respect. Language with karma words is a polite language used as the younger's form of respect to the older. The change of social factor determines the choice of speech level. In Javanese community, there is a change of attitude, in which not all people are willing to use krama form to speech partner or $\mathrm{O} 2$ because the speaker feels that the social status of speech partner is equal to the speakers' $(\mathrm{O} 1)$. In this situation, $\mathrm{O} 2$ tends to choose krama form as the form of respect to O1. Certain variables that can affect a speech are setting, participant, ends, act, key, instrumentalities, norm, and genre (Hymes). In Javanese language, the variables affecting the choice of speech form are, among others, setting and participant. These two variables are closely related to situational factor, while participants are related to social factor. When there is speech event, the speaker will consider the social factor of speech partner and situational factor when the speech event occurs. Social factor includes sex, age, kinship, position, education, income, place, time, topic, objective, and intimacy [16]. Different social factor of speech participants can result in symmetric and asymmetric, intimate and non-intimate relations, and the combination of the two. Situational factor also determines the form of speech used by speech participants, official and unofficial, formal and informal. 


\section{Results And Discussion}

Teaching book analyzed consists of two books: Widya Adi Basa Jawi published by Tiga Serangkai Pustaka Mandiri and Marsudi Basa lan Sastra Jawa published by Erlangga. These two books are composed based on the 2013 Curriculum for Language Local Content Subject. Teaching material contained in these two books feature the use of honorific forms in text, corresponding to social context [17]-[19]. The intended honorific form is the use of krama lexicon form in the text as the manifestation of respect to speech partner [20] .

\subsection{Signifier of Morphological Lexicon in the form of Affix}

Affixes dipun-, -ipun (-nipun), and -aken (-kaken) are the one signing krama lexicon.

(1) Lindhu utawi bumi kang horeg punika dumados amargi wontenipun lapisan nglebet bumi ingkang ewah.

'Earthquake occurs because the earth plates shift.'

(2) Lindhu punika saged dipunsababaken amargi wontenipun redi ingkang mbledhos. 'Earthquake occurs, among others, due to volcanic explosion.'

Suffix-ipun in words wontenipun 'the presence' in (1), confix dipun-/-aken in dipunsababaken 'is caused', is the signifier of krama lexicon. Suffix ipun, prefix dipun- , suffix -aken, and confix dipun-/-aken always join krama lexicon. The use of affix dipun-, ipun (nipun), and - -aken (-kaken) appears very often in daily speech. Affix dipun-, -ipun (nipun), -aken, -dipun/-aken, in addition to be inherent to krama lexicion, is also inherent to neutral lexicon.

\subsection{The signifier of non-morphological lexicon}

The signifier of krama lexicon is not a morphological signifier, the change of vocal sound and the change of syllable.

(3) Bena ingkang dumados wonten Kabupaten Kudus saestu nggegirisi manah. 'Flood occurring in Kudus Regency.

(4) Nawang Wulan boten gadhah kasekten, samenika menawi badhe adang sekul inggih kawiwitan nutu pantun dados uwos lajeng dipundang kados limrahipun manungsa ing alam ndonya.

'Nawang Wulan has no super power, now when she wants to cook rice should start with milling the paddy thereby becoming rice just like human being in general in the world.'

(5) Wondene ingkang njalari bena inggih menika ilining toya jawah ingkang teras-terasan tan wonten pedhotipun saking Pareden Kendheng.

'The cause of flood is the rainwater flowing continuously incessantly from Mount Kendheng.'

(6) Kajaba panggenan wisata kasebat, saperangan ageng tlatah wonten Pantura ingkang sisih tengen ugi kengeng bena.

'In addition to the tourist object, most area in western Panutra is also affected by flood'.

(7) Padamelan saben dintenipun inggih menika pados ron pisang tuwin ron jatos.

'His daily job is to look for banana and teakwood leaves.'

(8) Ron menika dipunlintokaken kaliyan uwos saha kabetahan sanesipun.

'The leaves are exchanged with rice and other needs.'

(9) Tindakipun dhateng peken ngantos pinten-pinten minggu amargi tebih saking kitha.

'Going to the market for weeks, as it is far from the city'.

(10) Asma kemawon boten mangertos kok badhe paring bebana dhateng kula. 
'Even I do not know your name, but you will give me a gift'.

(11) Boten usah muwun teras cah ayu, sekedhap malih slendang panjenengan mesthi kepanggih.

'Don't cry continuously the beautiful girl, your shawl will be found immediately'

(12) Bebana boten wigatos, ingkang wigatos slendhang kula wonten pundi?

'A gift is not important; the important thing is where my shawl is.'

(13) Sasmpunipun Nawang Wulan kesah dhateng lepen, kekep kabikakJaka Tarub.

'After Nawang Wulan goes to the river, Jaka Tarub opens the cover'.

(14) Sasampunipun Nawang Wulan kondur saking ngimbahisaha mangertosi bilih Jaka Tarub mbikak kekep ingkang sampun dados awisanipun kalawau, pramila Nawang Wulan duka sanget dhateng kakungipun.

'After Nawang Wulan coming home from washing cloth and finding that Jaka Tarub has opened the prohibited cover, Nawang Wulan was angry with her husband.

The finding above is the signifier of non-morphological krama lexicon in the change of vocal sound. The change of vocal sound occurs in the beginning and the end of word in ngoko lexicon changing into krama lexicon. This study finds the change of vocal sound [i] into [o], vocal sound $[\mathrm{u}]$ into $[\mathrm{a}]$, vocal sound $[\mathrm{u}]$ into $[\mathrm{i}]$, vocal sound [i] into [a], and vocal sound [i] into [o]. The change of ngoko vocal sound into the krama one can be seen in Table 1.

Table 1. List of ngoko lexicon vocal sound changing into krama one

\begin{tabular}{ll}
\hline Ngoko & Krama \\
\hline dumadi & dumados \\
jati & jatos \\
nganti & ngantos \\
ngerti & ngertos \\
wigati & wigatos \\
terus-terusan & teras-terasan \\
terus & teras \\
kasebut & kasebat \\
kabukak & kabikak \\
mbukak & mbikak \\
ngumbahi & ngimbahi \\
\hline
\end{tabular}

The finding shows the change of vocal sounds [i], dumadi, jati, nganti, ngerti, wigati, in ngoko lexicon into [o], dumados, jatos, ngantos, ngertos, wigatos, in krama lexicon. Vocal sound [u], terus-terusan, terus, kasebut, in ngoko lexicon, changes into lexicon [a], terasterasan, teras, kasebat, in krama lexicon.

\subsection{The choice of Lexicon Form}

The speech between speaker and speaker partner will surely consider social and situational factor of the speaker partner. Such the consideration will determine the form of speech to be used. In daily speech, if speaker (01) will respect speaker partner (02), 01 will use krama lexicon to 02 ; it is also true to the speaker partner. This study only describes the choice of krama lexicon, the speech used by 01 to respect 02 , with asymmetric relation. In asymmetric relation, the followings are possible to use: (1) 01 uses ngoko speech to 02 , while 02 use krama speech to 01 . It occurs when the social status of 01 is higher than that of 02 ; (2) 01 uses 
krama speech to 02 , while 02 uses ngoko speech to 01 . It occurs when the social status of 01 is lower than that of 02 .

(15) A: "Nuwun sewu, Pak badhe nyuwun priksa."

"Excuse me Sir, I want to get some information.

B : "O iya ana apa."

'Okay, can I help you?.'

(16) A: "Ayo, saiki PR e diijolke karo sisihe, terus dicocokne. "

'Let's exchange the homework with the adjacent friend.'

B: "Inggih, Bu."

'Yes, Madam.'

The speech discourse above shows an asymmetric relation. 01 uses Krama speech in (15a) to 02 (15b) using ngoko speech. Similarly in the speech occurring in sentence (16), 01 uses ngoko speech in (16a) to 02 in (16b) using krama speech.

\section{Conclusion}

This finding of research partially confirms an argument stating that the choice of honorific should consider social and situational factors. These two factors are represented in the choice of lexicon forms in a speech. In addition, this finding shows that the use of honorific form in teaching material can be seen in the use of ngoko and krama lexicons corresponding to situation and factor of speech partner. The choice of krama lexicon is used when the speech occurs with the respected speech partner, and vice versa, speech participant uses ngoko lexicon when the speaker or speech partner has symmetric or intimate relation.

The implication of research is that the finding can be utilized as teaching material in Javanese language learning. Material of honorific lexicon forms will increase knowledge and skill of communicating politely. In addition, the choice of lexicon form corresponding to social-cultural situation can be taken into account.

\section{References}

[1] J. E. Joseph, Language and Identity: National, Ethnic, Religious (1 ed.). New York: Palgrave Macmillan., 2004.

[2] M. Cleveland, M. Laroche, and N. Papadopoulos, "You are what you speak? Globalization , multilingualism, consumer dispositions and consumption," J. Bus. Res., pp. 1-11, 2014, doi: 10.1016/j.jbusres.2014.09.008.

[3] Y. Yoshimura, "Honorifics: A sociocultural verb agreement cue in Japanese sentence processing," vol. 31, pp. 551-569, 2010, doi: 10.1017/S0142716410000111.

[4] J. Mueller, C. Park, N. A. N. Jiang, and C. Park, "The Acquisition of the Korean Honorific Affix ( u ) si by Advanced L2 Learners," doi: 10.1111/j.1540-4781.2013.12005.x.

[5] N. Ifansyah and R. Q. Aini, "REALISASI KESANTUNAN BERBAHASA MAHASISWA MELALUI," pp. 302-307, 2017.

[6] L. Carson and E. Do, "Establishing a Korean language programme in a European Higher Education context: Rationale, curriculum and assessment procedures A rationale for learning Korean as a Foreign Language in a European Higher Education context,” vol. 3, no. 1, pp. 151171, 2013, doi: 10.1515/cercles-2013-0008.

[7] T. Xiong and Y. Qian, "Ideologies of English in a Chinese high school EFL textbook: A critical discourse analysis," Asia Pacific J. Educ., vol. 32, no. 1, pp. 75-92, 2012, doi: 10.1080/02188791.2012.655239. 
[8] W. Gedney, "Cultural-Linguistic Aspects in Asian Language Teaching. Proceedings of the First Annual Meeting of the American Council of Teachers of Uncommonly-Taught," no. 5.

[9] L. Brown, "Questions of appropriateness and authenticity in the representation of Korean honorifics in textbooks for second language learners," vol. 23 , no. 1, pp. 35-50, 2010, doi: $10.1080 / 07908310903474246$.

[10] L. Brown, "Teaching ' casual' and / or 'impolite' language through multimedia: the case of non-honorific panmal speech styles in Korean,” no. March 2015, pp. 37-41, 2013, doi: 10.1080/07908318.2012.745551.

[11] O. Yoshiko, "honorifics by addressing the question of how a Japanese speaker' $\mathrm{s}$ use of honorifics is Honorifics is one of the major areas of study in Japanese linguistics . The first strand in the literature is prescriptive and based on the traditional scholarly," 1998.

[12] T. Özşena and A. Özbekb, "A sociolinguistic and sociocultural approach to attitudinal dispositions of graduated students toward the business Japanese language.," Jpn. Ögretmenliği Mezunlarının İ̧̧ Jpn. Yönelik TutumsalEğilimlerinin Sosyolinguistik ve Sosyokültürel Anal., vol. 12, no. 1, pp. 32-41, 2016.

[13] Jateng, "Standar Isi Kurikulum Bahasa Jawa." 2014.

[14] S. S. Tr. W. Sasangka, "Unggah-Ungguh Bahasa Jawa.” Yayasan Paramalingua, Jakarta, 2004.

[15] K. Saddhono and M. Rohmadi, "A Sociolinguistics Study on the Use of the Javanese Language in the Learning Process in Primary Schools in Surakarta, Central Java, Indonesia.," Int. Educ. Stud., vol. 7, no. 6, pp. 25-30, 2014.

[16] J. A. Fishman, "Sociolinguistics-A Brief Introduction." Newburry House Publishers, Massachusetts, 1972.

[17] J. T. Irvine, "IDEOLOGIES OF HONORIFIC LANGUAGE," Int. Prasmatics A ssociation, 1970.

[18] S. Poedjosoedarmo, "Javanese Speech Levels," Southeast Asia Progr. Publ. Cornell Univ., vol. 6, no. 6, pp. 54-81, 2015.

[19] S. Poedjosoedarmo, "Wordlist of Javanese Non-Ngoko Vocabularies," Asia, Southeast Publ. Progr. Asia, Southeast Publ. Progr., vol. 7, no. 7, pp. 165-190, 2014.

[20] A. Adelaar and A. Adelaar, "Javanese - aké and - akən : A Short History Javanese - aké and - ak ə n : A Short History," vol. 50, no. 2, pp. 338-350, 2019. 